\title{
Mangrove expansion into temperate marshes alters habitat quality for recruiting Callinectes spp.
}

\author{
Cora A. Johnston ${ }^{1,3, *}$, Olivia N. Caretti ${ }^{2,4}$ \\ ${ }^{1}$ Department of Entomology, University of Maryland, College Park, MD 20742, USA \\ ${ }^{2}$ Department of Biology, St. Mary's College of Maryland, St. Mary's City, MD 20686, USA \\ ${ }^{3}$ Present address: Marine Science Institute, University of California, Santa Barbara, CA 93106, USA \\ ${ }^{4}$ Present address: Department of Marine, Earth \& Atmospheric Sciences, North Carolina State University, Raleigh, NC 27695, USA
}

ABSTRACT: Beyond direct habitat loss, climate change can alter habitat quality and availability by stimulating shifts in foundation species ranges. Tropical mangroves are proliferating at the intersection with temperate saltmarshes and continue moving poleward with unknown consequences for inhabitant marine fauna. We expected that mangrove and marsh foundation species differ in habitat quality, due at least in part to differences in their structural attributes, such that shifts from marsh to mangrove wetlands alter habitat availability for wetland inhabitants. We coupled recruitment surveys and laboratory experiments to assess the influences of foundation species' structural and non-structural attributes on Callinectes spp. recruitment, preference, and survival among mangrove and marsh habitats. Recruitment was evident in Spartina alterniflora and Rhizophora mangle intertidal habitats but not in Avicennia germinans. In laboratory trials, $S$. alterniflora was preferred in the presence of predation risk and provided the highest probabilities of survival, indicating that settlers can distinguish among ecotone vegetation types and that their choices correspond to habitat quality. Survival probability and recruit persistence were comparatively low in mangrove habitats. The differences in habitat use, preference, and survival identified in this study suggest that mangrove expansion is diminishing wetland habitat for Callinectes spp. It also reveals that changes between habitat-forming species, and not just the loss of structure per se, can affect habitat quality, such that foundation species may not replace one another functionally where they displace each other spatially.

KEY WORDS: Foundation species · Climate change · Biogenic habitat $\cdot$ Range shifts $\cdot$ Recruitment $\cdot$ Survival

*Corresponding author: coraann.johnston@gmail.com

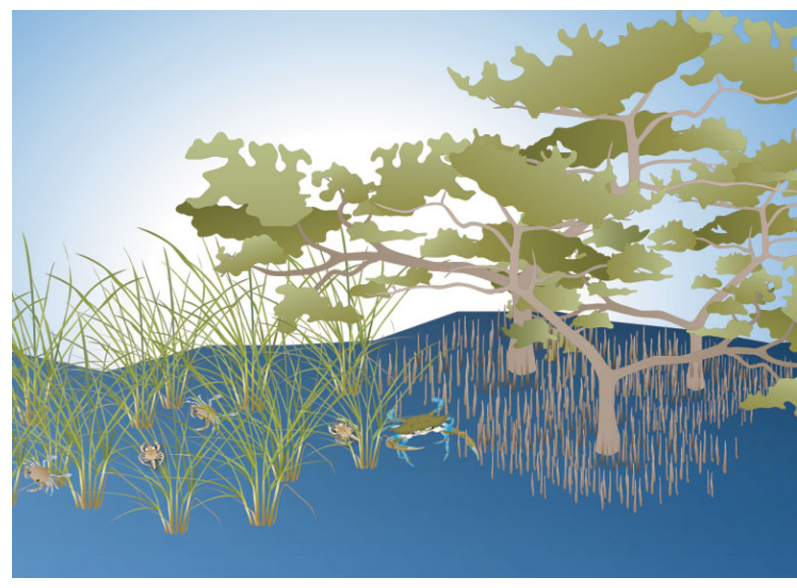

Recruiting Callinectes spp. distinguish between mangrove and marsh vegetation.

Image: C. Chenery, T. Saxby, J. Thomas, Integration and Application Network, University of Maryland Center for Environmental Science (ian.umces.edu/imagelibrary/).

\section{INTRODUCTION}

Population dynamics depend on the habitat that a species occupies, such that recruitment, survival, and growth often vary even among co-occurring habitat types (Minello et al. 2003, Grol et al. 2011, Johnston \& Lipcius 2012). Thus, changes in habitat availability can alter inhabitant population dynamics. Climate change and anthropogenic stressors are modifying marine habitats by reducing the abundance of habitatforming species (Harley et al. 2006, Hoegh-Guldberg \& Bruno 2010). Where foundation species are lost, secondary declines of inhabitant fauna are attributed

() The authors 2017. Open Access under Creative Commons by Attribution Licence. Use, distribution and reproduction are unrestricted. Authors and original publication must be credited. 
to reduced habitat quality with the loss of structural complexity (e.g. transitions from coral reef to algal turf and kelp forest to urchin barrens; Knowlton 2001, Steneck et al. 2002, Feary et al. 2007, Ling 2008). Climate change is also redistributing species geographically, which can cause foundation species to replace one another without a loss of biogenic habitat per se (Stachowicz et al. 2002, Poloczanska et al. 2013). Accordingly, inhabitant fauna have declined less markedly where one structurally complex habitat is replaced by another (e.g. seagrass to macroalgae; Johnston \& Lipcius 2012). With an increasing recognition of wide-spread shifts in species distributions, there is a growing need to understand how habitat use and inhabitant population dynamics differ between shifting foundation species.

Throughout the world, coastal wetlands are being reshaped by the poleward shift of tropical mangroves into temperate saltmarshes (Osland et al. 2013, Cavanaugh et al. 2014, Saintilan et al. 2014). Many macrofauna species use mangroves or saltmarshes as nursery habitat, but the vegetation types likely differ as habitat because their intertidal components differ in growth form (Robertson \& Duke 1987, Minello et al. 2003, Friess et al. 2012). The ecotone along the Atlantic coast of Florida (USA) is dominated by 3 plant species with distinct intertidal growth structures: Spartina alterniflora (smooth cordgrass) forms tall shoots of flat-bladed leaves that branch upward from a central stem; Rhizophora mangle (red mangrove) prop roots are tall, with secondary roots branching downward from primary roots; Avicennia germinans (black mangrove) produce shorter, simple emergent pneumatophores (Fig. 1). We hypothesize that these mangrove and marsh vegetation types provide non-equivalent wetland habitats, due in part to influences of their structural attributes on habitat use and inhabitant survival (Friess et al. 2012, Sepúlveda-Lozada et al. 2015).

To better understand how climate-driven shifts in foundation species affect inhabitant species, we studied the distribution of Callinectes spp. (Decapoda: Portunidae) recruits among mangrove and marsh biogenic habitats where they co-occur, paying particular attention to the effects of differences in vegetation structural attributes on habitat use. Specifically, we (1) monitored a recruiting cohort of Callinectes spp. on an experimental array deployed in patches of mangrove and marsh vegetation in the ecotone and (2) tested the underlying drivers of habitat use patterns with settling Callinectes spp. in the laboratory. We expected recruits to use mangrove and marsh vegetation differently, and that differ-
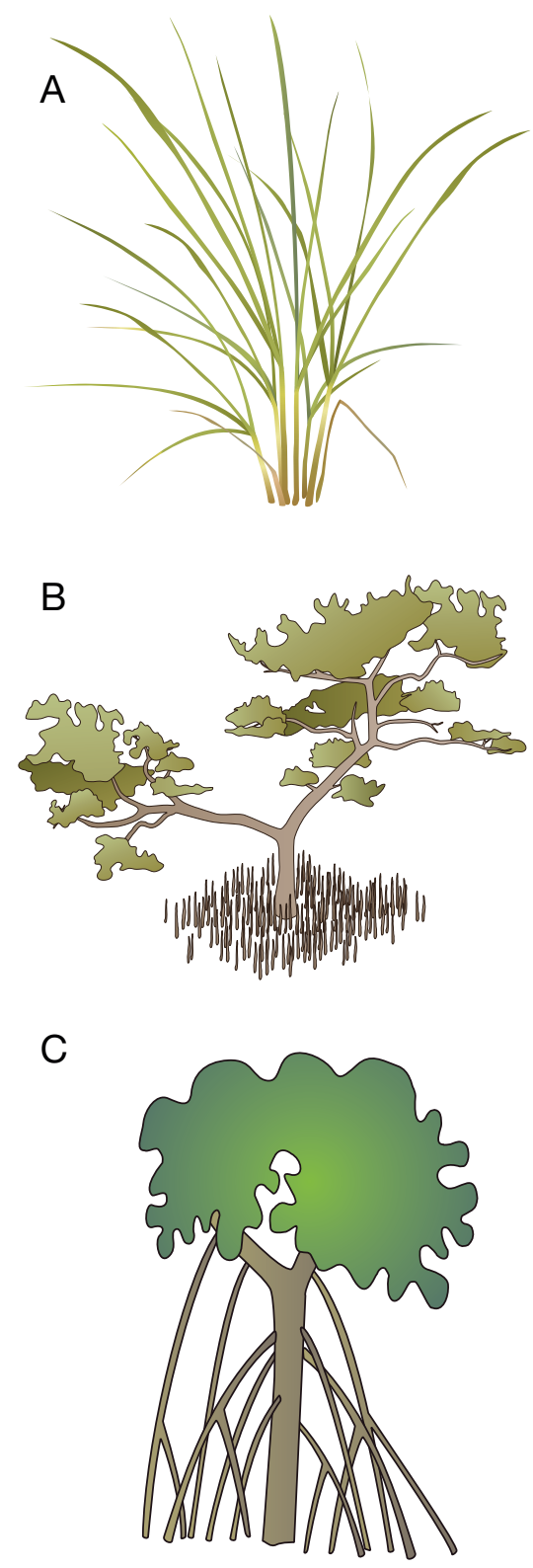

Fig. 1. The 3 vegetation types studied are (A) Spartina alterniflora (cord grass) shoots, (B) Avicennia germinans (black mangrove) pneumatophores, and (C) Rhizophora mangle (red mangrove) prop roots. Vegetation illustrations: T. Saxby and J. Thomas, Integration and Application Network, University of Maryland Center for Environmental Science (ian.umces.edu/imagelibrary/)

ences in habitat use originate from active habitat selection (hereafter 'preference') or from subsequent post-settlement mortality (Houde 1987, Etherington \& Eggleston 2000, Heck et al. 2001). The differences in habitat use, preference, and survival identified in this study suggest that shifts in foundation species and their structural attributes alter habitat quality and availability for Callinectes spp. 


\section{MATERIALS AND METHODS}

\section{Study system}

An undifferentiated mix of Callinectes sapidus and Callinectes similus (hereafter Callinectes) were the focal organisms in all study components. These swimming crabs settle as megalopae in near-shore environments in the southeast USA, and are dependent on wetlands as nursery habitat (Orth \& van Montfrans 1987, Hsueh et al. 1993, Epifanio 1995, Etherington \& Eggleston 2000). To evaluate changes in habitat quality for Callinectes with mangrove expansion, we examined habitat formed by temperate Spartina alterniflora (saltmarsh cordgrass), tropical Avicennia germinans (black mangroves) and Rhizophora mangle (red mangroves), hereafter referred to by generic names.

Specifically, we evaluated habitat value and crab use of the vegetation components that occupy the intertidal water column-grass shoots and aerial mangrove roots. To parameterize our experimental units, we first measured structural attributes of naturally occurring vegetation at 4 sites spanning the ecotone $\left(27.8-30.4^{\circ} \mathrm{N}\right)$. Each vegetation type was surveyed in at least 3 sites. Sampling areas $(n=20)$ were identified by selecting a randomly drawn number that corresponded to a point along a haphazardly chosen strip of shoreline. Within a $1 \mathrm{~m}^{2}$ plot at each sampling area, we recorded vegetation cover and composition, the presence of branching, and the number of elements: roots or shoots. Within a $0.25 \mathrm{~m}^{2}$ subplot, we measured angles of articulation and element diameters $10 \mathrm{~cm}$ above the substrate. Experimental vegetation units were then constructed to match field measures of vegetation density, diameter, and articulation.

\section{Field studies: recruitment}

We established a landscape-scale field experiment to assess habitat associations of recruiting Callinectes in the mangrove-marsh ecotone throughout the recruitment season (May to November 2014). We used an array of retrievable panels to conduct equal sampling with a single method across emergent shoot and pneumatophore and overhanging prop root vegetation structures. The experiment was designed to test recruitment response both (1) by habitat type at the scale of $10 \mathrm{~s}$ of meters and (2) by physical structure at the scale of 10 s of centimeters. Retrievable panels were fitted with artificial vegeta- tion mimics and deployed in patches of each habitat type, such that comparisons by panel indicate the influences of physical structure, while grouping by habitat type indicates responses to broader habitat attributes such as chemical cues, production, or shading (Fig. 2A). Recruitment was monitored across 2 sites, Halifax River and Matanzas River, Florida, within the mixed vegetation ecotone (Fig. 2B). Halifax River $\left(29.09^{\circ} \mathrm{N}, 80.94^{\circ} \mathrm{W}\right)$ is a mangrove-dominated site north of Cape Canaveral that has small stands of Spartina that persist along shallow, sandy banks. Some $70 \mathrm{~km}$ further north, Matanzas River $\left(29.67^{\circ} \mathrm{N}, 81.21^{\circ} \mathrm{W}\right)$ is a historically saltmarshdominated site south of St. Augustine where mangroves have been proliferating since at least the 1980s (Cavanaugh et al. 2014, Rodriguez et al. 2016); Avicennia are abundant, while Rhizophora are still rare.

At each site, habitat patches were selected adjacent to main waterways within $4.5 \mathrm{~km}$ of the inlet to minimize spatial variation in larval supply and environmental conditions (Etherington \& Eggleston 2000, Paula et al. 2001). Across sites, habitat patches were selected to provide a continuous edge of a single vegetation type with a total intertidal patch area $>15 \mathrm{~m}^{2}$. All patches had mixed sand, mud, and oyster substrates. A total of 4 patches per vegetation type were selected ( $\mathrm{n}=12$ patches total), with 6 patches at each site allocated according to the natural abundance of each vegetation type (3 Spartina, 2 Avicennia, and 1 Rhizophora patch at Matanzas; 1 Spartina, 2 Avicennia, and 3 Rhizophora patches at Halifax).

To conduct the study, retrievable $61 \times 61 \mathrm{~cm}$ panels were constructed from $1 / 2$ inch $(\sim 1.27 \mathrm{~cm})$ non-pressure treated plywood and populated with artificial vegetation structures. Vegetation structures were affixed to the central $50 \times 50 \mathrm{~cm}\left(0.25 \mathrm{~m}^{2}\right)$, leaving a $5 \mathrm{~cm}$ outer border for anchoring and retrieval. Avicennia pneumatophores were constructed from $0.64 \mathrm{~cm}$ diameter birch dowels $(24-27 \mathrm{~cm}$ tall). Rhizophora prop roots were constructed from a variety of 1.3 and $1.9 \mathrm{~cm}$ diameter birch dowels, composed of 6-7 'mainstems' with 2-3 lateral roots each affixed at $\sim 60^{\circ}$. Spartina shoots were composed of $3 \mathrm{~mm}$ diameter PVC rod with polyester leaves glued at regular intervals ( 5 blades per shoot); green plastic straws were placed over the lower stem to increase the diameter to $\sim 4.6 \mathrm{~mm}$. Within the $0.25 \mathrm{~m}^{2}$ center of each panel, 1 of the 3 vegetation types was added at natural densities (mean \pm SD: $227 \pm 99$ pneumatophores, $85 \pm 35$ prop roots, or $150 \pm 41$ shoots per $\mathrm{m}^{2}$ ).

Panels were deployed along the periphery of habitat patches in a balanced design across sites. Panels, anchored flush with the benthos, were 

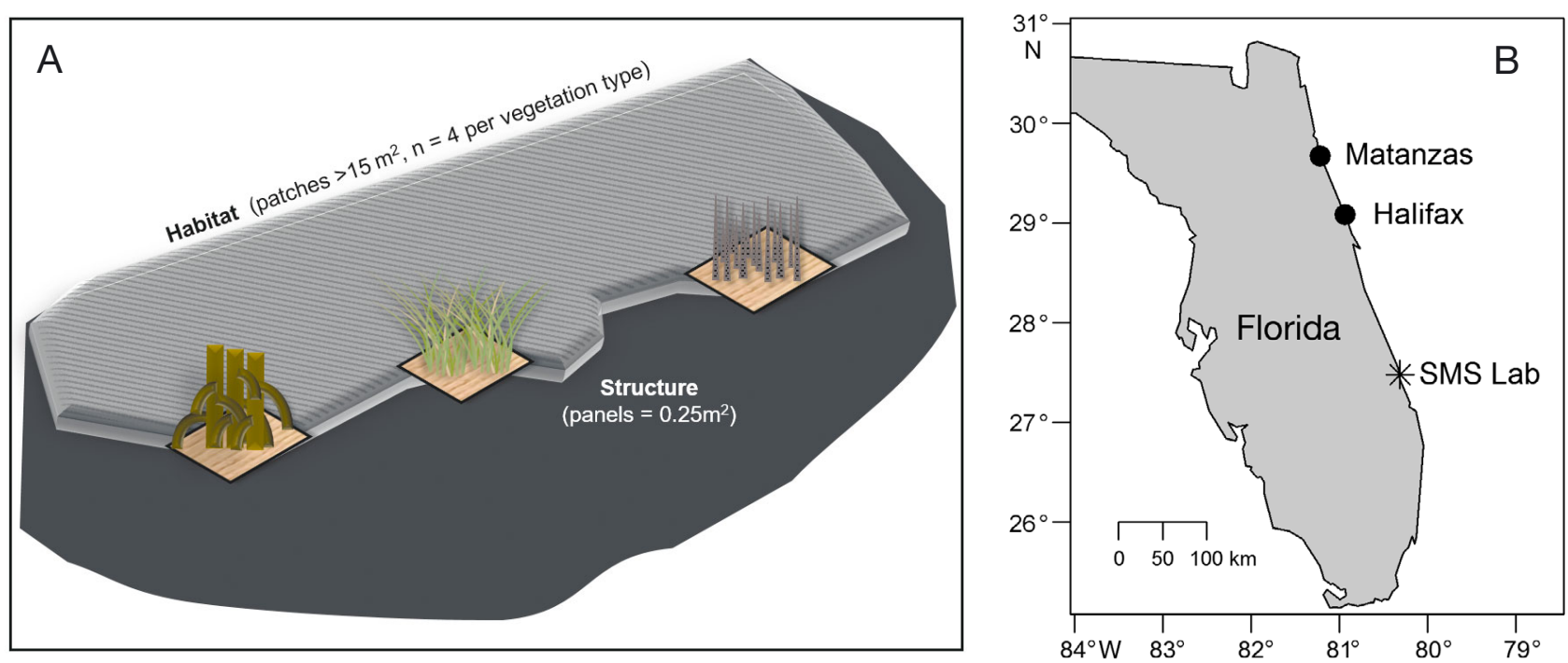

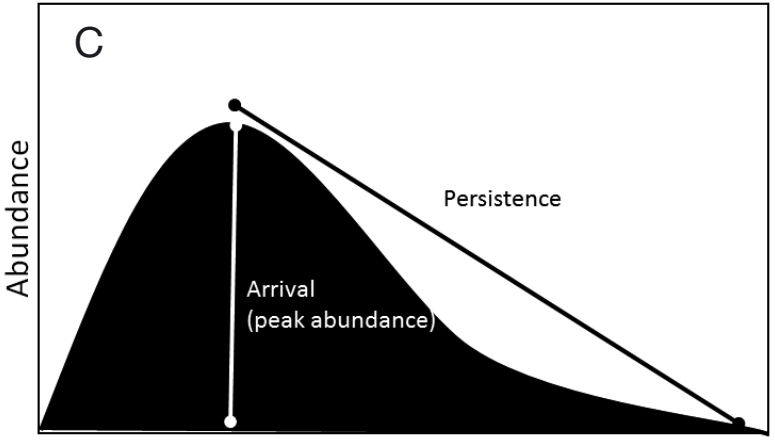

Time
Fig. 2. (A) For the recruitment study, $0.25 \mathrm{~m}^{2}$ panels outfitted with each structure type were deployed in replicate patches of each habitat type. (B) Recruitment was studied at 2 sites (black circles) along the ecotone on the Northern Atlantic coast of Florida, USA. Laboratory trials were conducted at the Smithsonian Marine Station (SMS) in Fort Pierce (asterisk). (C) Recruitment was evaluated in terms of initial arrival and subsequent recruit persistence. The optimal habitat would have high peak abundance followed by high persistence (i.e. shallow slope). (D) Preference arena design: side view (left), cross section (center, shown with Spartina), and aerial view (right). Arena illustration: O. N. Caretti

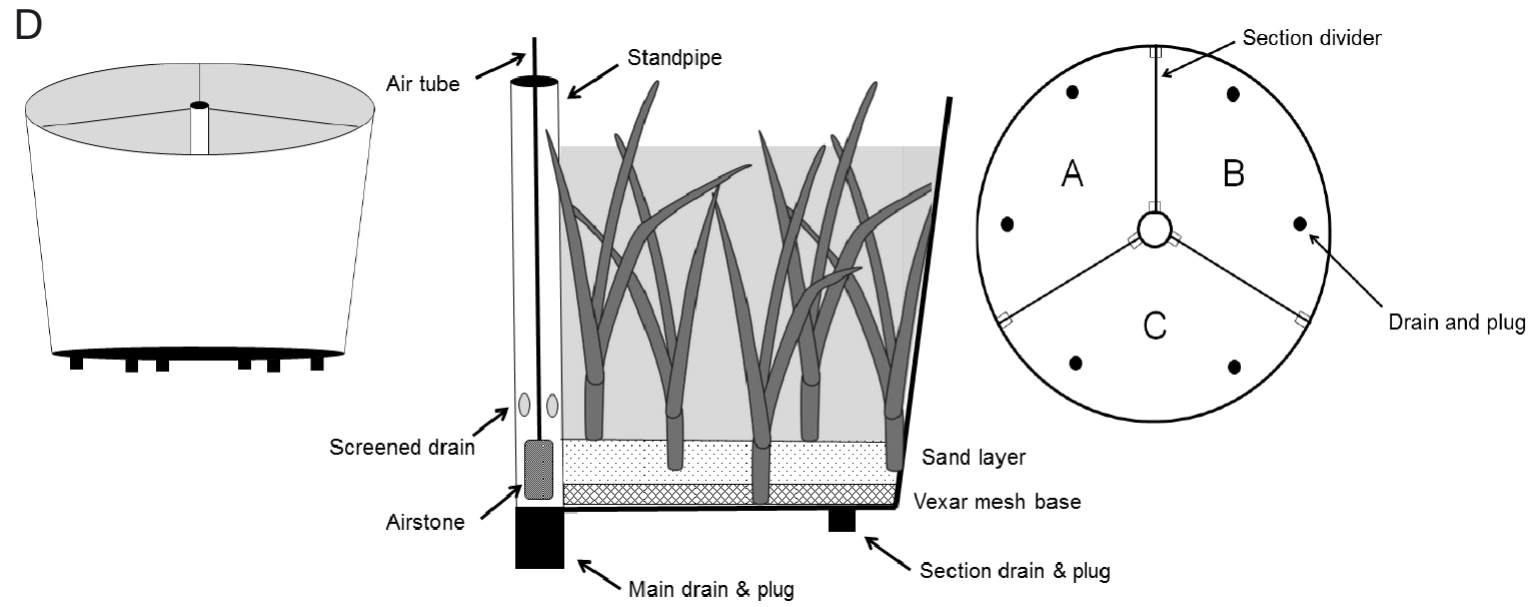

deployed in triplicate, with one panel of each vegetation structure placed within each habitat type in a fully crossed design ( $\mathrm{n}=36$ panels total or 12 per structure type across habitats and 12 within each habitat type; method as in Lindsey et al. 2006, Pardo et al. 2007; Fig. 2A). During panel sampling, a cube lined with $1 \times 2 \mathrm{~mm}$ mesh on all but one side-edged with foam-rubber-was placed over a panel, pressed down to create a seal, and secured (Brainard et al. 2009). The entire unit was retrieved, and the contents were rinsed through a $500 \mu \mathrm{m}$ sieve and examined for Callinectes recruits. Recruits were measured and released. Panels were immediately redeployed. The panels were deployed in May 2014 and monitored 
every 2 wk within $3 \mathrm{~d}$ of full and new moons to maximize recruitment detection. Once recruitment began in late summer, monitoring continued until early November; at which time water temperatures fell, abundance returned to pre-recruitment levels, and crabs reached 15-20 mm carapace width (CW), when secondary dispersal is expected (Lipcius et al. 2007, Johnston \& Lipcius 2012). We used the resultant 10 weeks of cohort occurrence data to examine differences in recruitment dynamics, especially arrival and persistence, by habitat type (Fig. 2C).

For analysis, data was constrained to samples from late August through early November to characterize the recruiting cohort. All models of recruitment by habitat type included a random effect of patch identity to account for replicate panels within each patch. Generalized additive models (GAM) were used to fit smoothing functions to recruitment abundance in each habitat and each structure type across dates ('mgcv' package in R; Wood 2006, R Core Team 2015). We identified a recruitment pulse as the significant fit of a smoother to a change in recruit abundance over time. A smoother of salinity was also included in each model to account for variation in recruit abundance with salinity fluctuations throughout the study period.

To further characterize recruitment dynamics, we analyzed abundance during peak recruitment in late September and at subsequent dates until differences in abundance by habitat type or structure type were no longer significant $(p>0.05)$. Differences in abundance were analyzed with generalized linear mixed effects models with a Poisson distribution using the 'glmer' function in the 'Ime4' package in R (Bates et al. 2015). Predictor level responses were assessed with Tukey post-hoc comparisons using the 'glht' function in the 'multcomp' package (Bretz et al. 2016). Together, recruit arrival and persistence were used as indicators of habitat use and quality (Fig. 2C). Also, in all study components (recruitment, preference, and survival), Spartina was specified as the intercept for all linear model analyses based on the logic that mangroves are encroaching on the saltmarsh landscape.

\section{Laboratory experiments}

We conducted habitat preference and survival studies with settling crabs during peak Callinectes recruitment in May, August, and September 2015 and May 2016. Both studies were conducted at the Smithsonian Marine Station in Fort Pierce, Florida,
USA. Seawater was provided via a flow-through system that delivers sand-filtered water directly from the adjacent Indian River Lagoon. During the study dates, lagoon waters near the study site had a mean salinity $( \pm \mathrm{SD})$ of $33 \pm 4$ and mean temperature of $25 \pm 3^{\circ} \mathrm{C}$ (sensor 0054, Harbor Branch Oceanographic Institute Land/Ocean Biogeochemical Observatory). Vegetation used in each study was collected fresh, scrubbed, and rinsed with fresh water to remove biofilms and epibionts (van Montfrans et al. 2003).

To populate the studies, megalopae and early juvenile (hereafter J1) Callinectes were collected by plankton net in Fort Pierce Inlet $\left(27.48^{\circ} \mathrm{N}, 80.31^{\circ} \mathrm{W}\right)$ during incoming night tides within a week of full or new moon. Each study was populated with high but realistic densities of settlers (110-120 megalopae or 65-88 J1 per $\mathrm{m}^{2}$ in preference trials and 75-94 megalopae or $\mathrm{J} 1$ per $\mathrm{m}^{2}$ in survival trials; maximum documented natural recruitment is $\sim 150$ megalopae per $\mathrm{m}^{2}$ : Moksnes 2002, van Montfrans et al. 2003). Developmental stage did not influence results in any trial, thus megalopae and J1 data are analyzed and presented together. We used sub-adult portunid crabs, which readily cannibalize conspecific recruits and first instar juveniles, as the predators in survival and risk trials (Smith 1995, Hines \& Ruiz 1995, Moksnes et al. 1997, Aumann et al. 2006). Small portunids (16-36 mm CW) were collected with a push net in shallow flats adjacent to the laboratory, then held in separate $\sim 2$ l tanks until each experiment $(<48 \mathrm{~h}$ holding time).

\section{Preference}

Settler preference for mangrove and marsh vegetation with and without risk (predator cues) was tested at night in ambient outdoor conditions with a pair of multi-section arenas. In preference tests, we simultaneously offered each vegetation type to settling crabs within a subdivided circular arena (van Montfrans et al. 2003). Each $200 \mathrm{l}$ arena (bottom surface $=0.28 \mathrm{~m}^{2} ; 64 \mathrm{~cm}$ bottom width $[77 \mathrm{~cm}$ top width] $\times 42 \mathrm{~cm}$ height) contained a center stand pipe for infrastructure, aeration, and drainage (Fig. 2D). Removable dividers split each arena into 3 individually draining $900 \mathrm{~cm}^{2}$ sections. Sections were outfitted with freshly harvested mangrove or marsh vegetation that was fixed haphazardly to plastic mesh screens at low but realistic densities (55 prop roots, 110 pneumatophores, or 92 grass shoots per $\mathrm{m}^{2}$ ). Vegetation was assigned to random- 
ized arena sections, then sand pre-washed and sieved to $<500 \mu \mathrm{m}$ grain size was added until the mesh was covered and the vegetation stood upright ( $5 \mathrm{~cm}$ sand depth). The arenas were filled to $30 \mathrm{~cm}$ with sand-filtered ambient seawater. To assess the influence of risk on habitat preference, 2 portunid predators (described in the previous section) were added to each standpipe in half the trials. Meshcovered openings between the standpipe and each section allowed predator chemical cues to enter the arena without any risk of actual predation (Griffiths \& Richardson 2006, Smee \& Weissburg 2006). Aeration within each standpipe increased water flow, circulating predator cues from the pipe into the broader arena. Arenas, sand, and vegetation were thoroughly rinsed with fresh water between trials.

At the start of each trial, dividers were placed between the vegetation types. Equal numbers of settling crabs (6-8 J1 or 10-11 megalopae) were added to each section to simulate a random distribution, the expected condition for no preference (van Montfrans et al. 2003). After 5 min of acclimation, dividers were removed to allow crabs to freely move about the arena for 12-14 h between 18:30-09:30 h, when megalopae are most active due to natural nocturnal ingress behavior (Epifanio 1995, Tankersley et al. 2002, van Montfrans et al. 2003, Moksnes \& Heck 2006). At the end of each trial, dividers were simultaneously returned to each arena and water was drained down to $\sim 10 \mathrm{~cm}$ depth through the central standpipe (lined with $<500 \mu \mathrm{m}$ mesh to prevent settler loss). Section plugs were then removed simultaneously so that the remaining water, sand, and settlers drained in unison from each section into a corresponding bucket below. Vegetation was rinsed and visually inspected for settlers. Finally, the drained contents of each section were filtered through a $710 \mu \mathrm{m}$ sieve, allowing the $<500 \mu \mathrm{m}$ sand to pass through while retaining the $\sim 1 \mathrm{~mm}$ settled crabs. Preference and avoidance were evaluated as changes in the number of crabs per section from the initial even distribution using a repeated G-test (chisquare framework) in R version 3.2.3 (R Core Team 2015). Only trials with $\geq 80 \%$ recapture efficiency were included in final analyses. Expected values for each habitat per trial were calculated as 1/3 (3 habitats per tank) of the total number of recovered settlers per trial. For significant G-test results, the habitats driving overall differences were identified as those with standardized residuals $>|2|$ from corresponding chi-square tests, indicating significant deviation from the null expectation for a given habitat (Sharpe 2015).

\section{Survival}

Settler survival was assessed during the day under ambient conditions in an open air flow-through laboratory. Each sub-adult predator was fasted for $12 \mathrm{~h}$ prior to survival trials (8-10 h stomach clearing time; McGaw \& Reiber 2000). Satiation trials were conducted to ensure that juvenile portunids are effective megalopae predators and that consumption in survival trials was not limited by predator satiation. To test satiation, individual fasted portunid predators $(\mathrm{n}=32$ ) were added to tanks containing only seawater, an airstone, and $4 \mathrm{~J} 1$ or 6 megalopae (4-5 maximum used in survival trials). After $7 \mathrm{~h}$ (comparable to survival trial duration), predators were removed and surviving settlers counted. Ninety percent of prey was consumed on average, with $100 \%$ consumed in $70 \%$ of satiation trials, indicating that predator satiation is not a limiting factor in our survival trials.

Differences in survival by vegetation type were tested in a series of $530 \mathrm{~cm}^{2}$ circular tanks $(26 \mathrm{~cm}$ width $\times 44.28 \mathrm{~cm}$ height) containing only one vegetation type each. Tanks were haphazardly assigned to each vegetation type or an unvegetated sand treatment. Treatment tanks were outfitted with mangrove or marsh vegetation fixed to plastic mesh screens as in preference trials. Pre-sieved and rinsed sand $(<500 \mu \mathrm{m}$ grain size) was added until the mesh was covered and the vegetation stood upright ( $\sim 5 \mathrm{~cm}$ sand depth). The unvegetated control treatment received only $5 \mathrm{~cm}$ of sand. Tanks were filled to $30 \mathrm{~cm}$ with sand-filtered ambient seawater and aerated with a single air stone. Four J1 or 5 megalopae were placed in each tank and given $20 \mathrm{~min}$ to acclimate before 1 portunid predator (described in 'Laboratory experiments' above, $22 \pm 0.4 \mathrm{SE}$ mm mean CW) was added to each tank. Trials ran for $\sim 6 \mathrm{~h}$ in ambient daylight between 09:00 and 19:00 h. At the end of each trial, predators were removed and tanks were drained, rinsed, and sieved as in preference trials. A series of predator-free control trials $(\mathrm{n}=10 \mathrm{sets})$ revealed that settler recovery was $95-100 \%$ efficient in the absence of predators, indicating no vegetationspecific recovery bias. Thus, all settlers missing from predation trials were considered depredated. Survival probability was measured as the proportion of settlers recovered. Based on our hypotheses, survival was analyzed relative to habitat type using generalized linear models in the 'mass' package in $\mathrm{R}$ with a quasibinomial family to account for overdispersion (Venables \& Ripley 2002, R Core Team 2015). Treatment level responses were assessed with Tukey post-hoc comparisons between predictor levels with the 'glht' function in the 'multcomp' package (Bretz et al. 2016). 


\section{RESULTS}

\section{Recruitment}

We evaluated Callinectes recruitment responses to both (1) habitat type of large patches and (2) physical structure of vegetation mimics within patches. A recruiting cohort was first detected in early September 2014 and reached peak abundance in late September. Recruits were twice as abundant, on average, at the Halifax River site (mangrove dominated; 7.6 recruits per $\mathrm{m}^{2}$ on average compared to 3.6 at Matanzas River); nonetheless, site did not significantly contribute to model fit, and habitat associations remained consistent when standardized by recruit availability for each site and sampling date. Thus, results are presented for raw data, unstandardized by site.

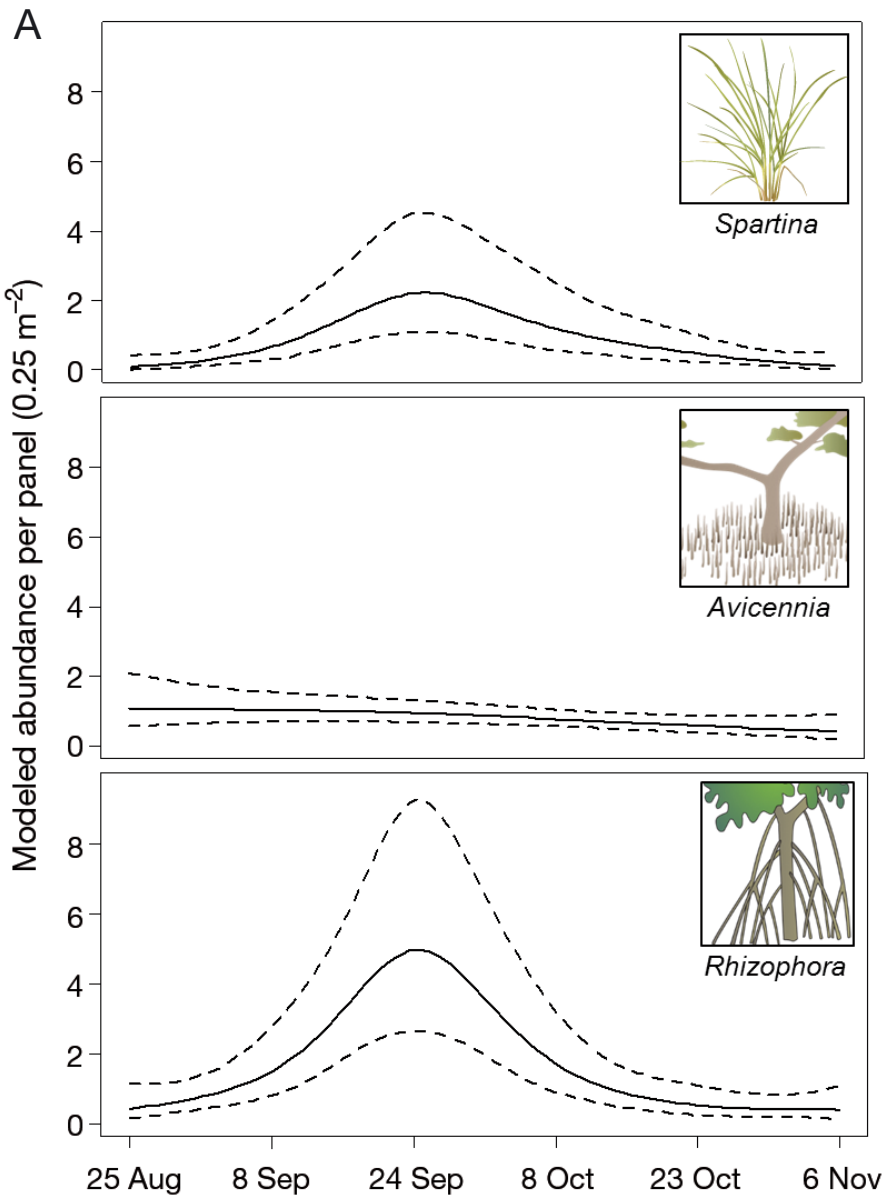

Significant recruitment pulses were detectable in Spartina (GAM temporal smoother $\chi^{2}=18.8$, edf $=$ $3.3, \mathrm{p}=0.0009)$ and Rhizophora habitat patches $\left(\chi^{2}=\right.$ 24.6, edf $=3.8, \mathrm{p}<0.0001$ ) but not in Avicennia habitat patches $\left(\chi^{2}=3.3\right.$, edf $=1.4, p=0.24$; Fig. 3A). In recruitment comparisons by date, late September peak abundance in Rhizophora habitat (mean \pm SE: $32 \pm 8$ settlers per $\mathrm{m}^{2}$ ) was marginally higher compared to Spartina $\left(13 \pm 4\right.$ settlers per $\mathrm{m}^{2}$, GLMER residual $\mathrm{df}=3, \mathrm{p}=0.0837$ ) and significantly higher than in Avicennia ( $8 \pm 3$ settlers per $\mathrm{m}^{2}, \mathrm{p}=0.0106$; Likelihood Ratio Test $\chi^{2}=36.8, \mathrm{n}=4$ patches per habitat type, with recruits sampled on 3 panels in each patch; Fig. 3B). Recruit persistence from peak abundance to the subsequent sampling date was lowest in Rhizophora habitat (0.28), with higher persistence in Avicennia (0.57) and Spartina (0.45), such that within 2 wk (early October) recruit occupancy
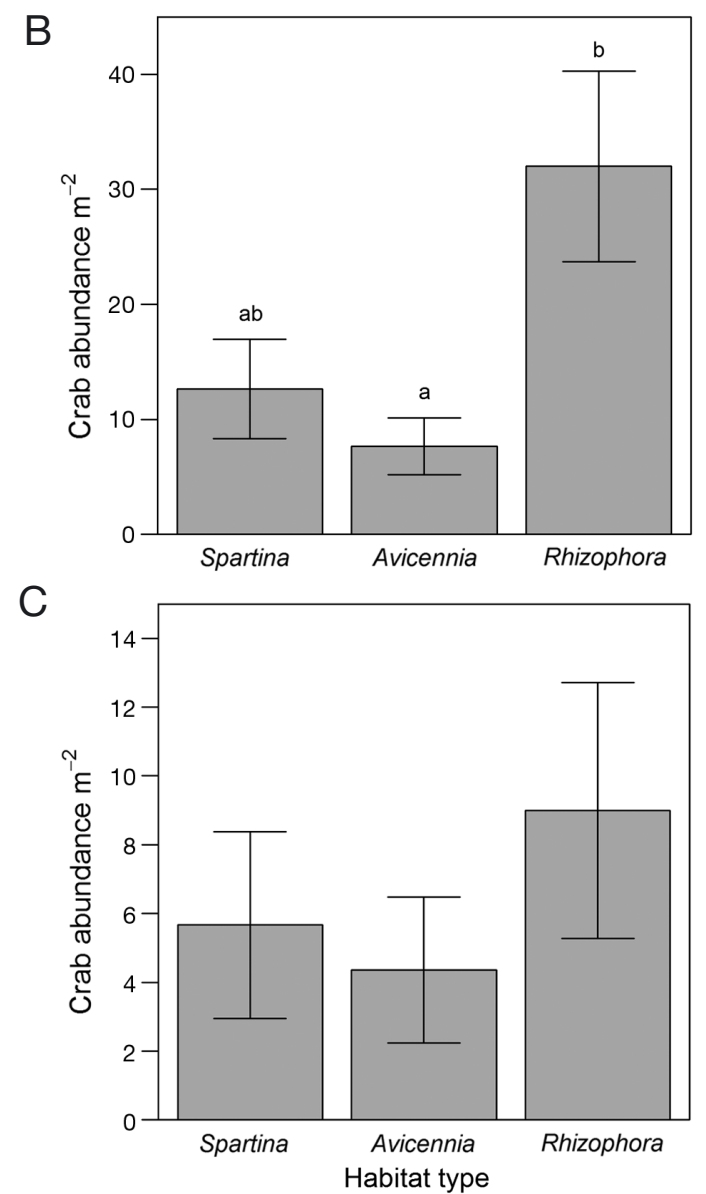

Fig. 3. (A) Modeled abundance of settling Callinectes in patches of 3 vegetation types in the field. Solid lines plot the fitted smoother (generalized additive model); dashed lines represent \pm 2 SE. (B) Settling Callinectes abundance by vegetation type at initial (peak) abundance in late September. (C) Callinectes abundance 2 wk after peak recruitment (early October) demonstrates differences in recruit persistence. Lettering indicates significant differences at $p<0.05$. Note difference in abundance scales between September (B) and October (C). Credits for vegetation illustrations: see Fig. 1 
was no longer significantly different by habitat type (GLMER residual df $=29, \mathrm{p}=0.075$; Fig. 3C).

Recruits also responded to isolated vegetation structures. Recruitment pulses occurred in grass shoot (GAM temporal smoother $\chi^{2}=23.34$, edf $=3.8, \mathrm{p}=$ $0.0001)$ and prop root structures $\left(\chi^{2}=13.32\right.$, edf $=2.9$, $\mathrm{p}=0.0077)$ but not in pneumatophores $\left(\chi^{2}=6.57\right.$, edf $=$ $2.3, p=0.11$; Fig. 4A). During peak abundance in late September, recruit abundance was highest on grass shoots $\left(30 \pm 9\right.$ settlers per $\left.\mathrm{m}^{2}\right)$ and significantly lower on pneumatophores $\left(13 \pm 4\right.$ settlers per $\mathrm{m}^{2}$, GLMER residual $\mathrm{df}=30, \mathrm{p}<0.0001)$ and prop roots $(10 \pm 3$ settlers per $\mathrm{m}^{2}, \mathrm{p}<0.0001 ; \chi^{2}=6.8, \mathrm{n}=12$ panels per structure type; Fig. 4B). As with habitat patches, differences in persistence eliminated any difference in abundance by physical structure type within $2 \mathrm{wk}$ (GLMER residual df $=29, \mathrm{p}=0.775$; Fig. 4C).

A
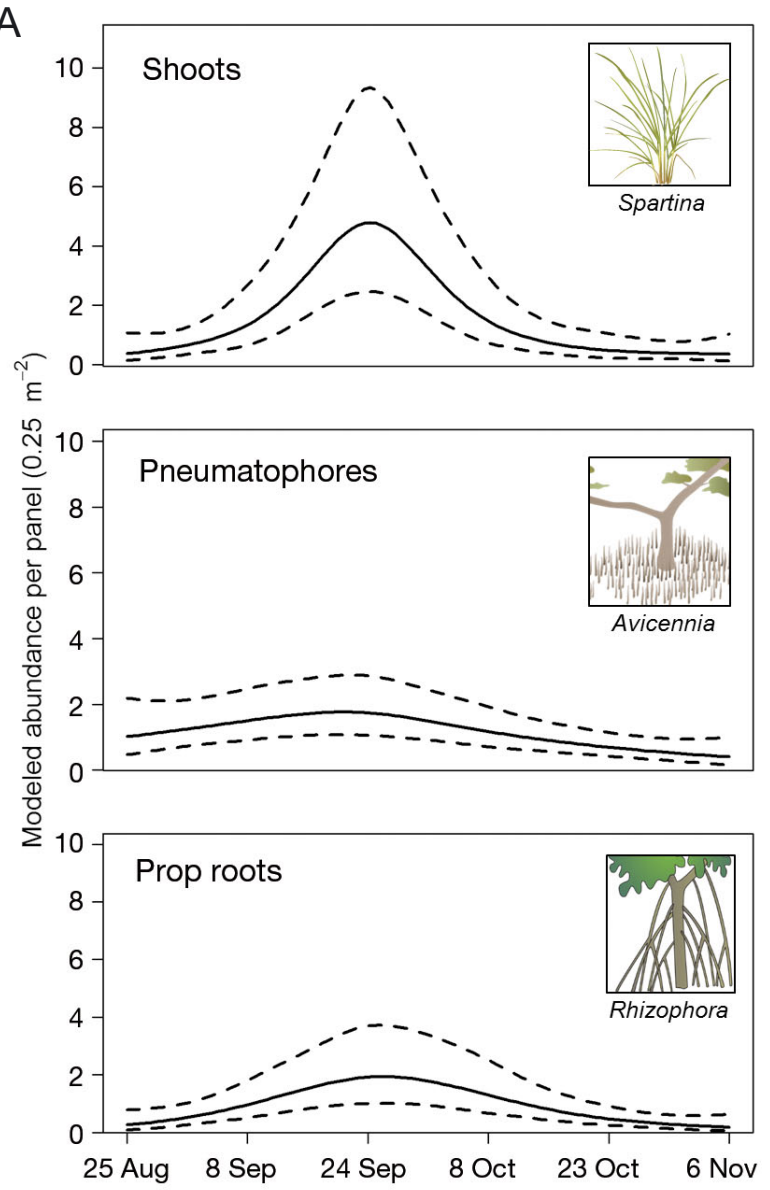

\section{Preference}

To determine whether recruitment patterns in the field are driven by active preference, we tested settler habitat preference in the laboratory. In the absence of predation risk, settlers did not display a preference between habitat types (individual G-test for no risk: $\mathrm{n}=16$ trials, $\mathrm{df}=2, \mathrm{p}=0.58$ ). Although they remained non-significant, differences in habitat preference strengthened markedly in the presence of predation risk (heterogeneity G-test by risk presence/absence: $\mathrm{df}=2, \mathrm{p}=0.09$ ). In risk trials, Spartina shoots were preferred marginally over mangrove vegetation (individual G-test for risk: $\mathrm{n}=16$ trials, $\mathrm{df}=2, \mathrm{p}=0.07$ ). Unexpected variation in preference by season emerged, with settlers distinguishing between habitat significantly more in the fall than
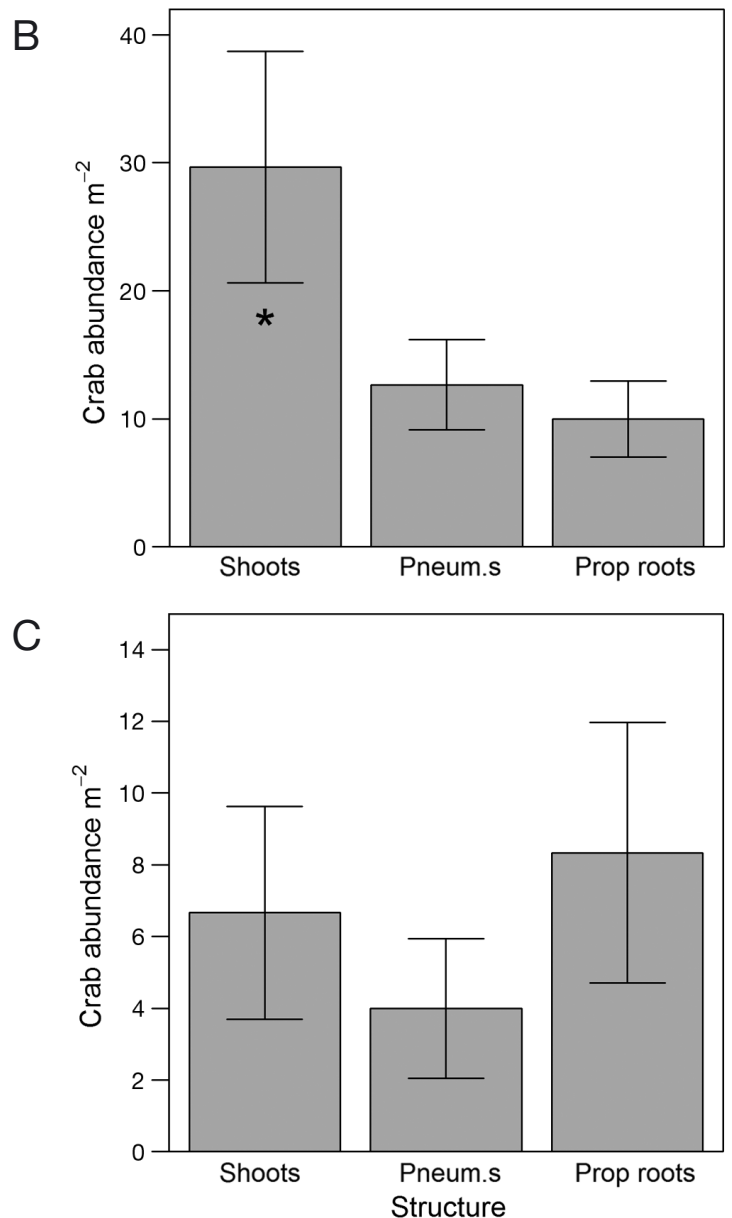

Fig. 4. (A) Modeled abundance of settling Callinectes in structural mimics of each vegetation type in the field. Solid lines plot the fitted smoother (generalized additive model); dashed lines represent \pm 2 SE. (B) Settling Callinectes abundance by structural mimic type at initial (peak) abundance in late September. (C) Callinectes abundance by structure type 2 wk after peak recruitment (early October) demonstrates differences in recruit persistence. Asterisk indicates significant differences at $\mathrm{p}<0.05$. Note difference in abundance scales between September (B) and October (C). Credits for vegetation illustrations: see Fig. 1 

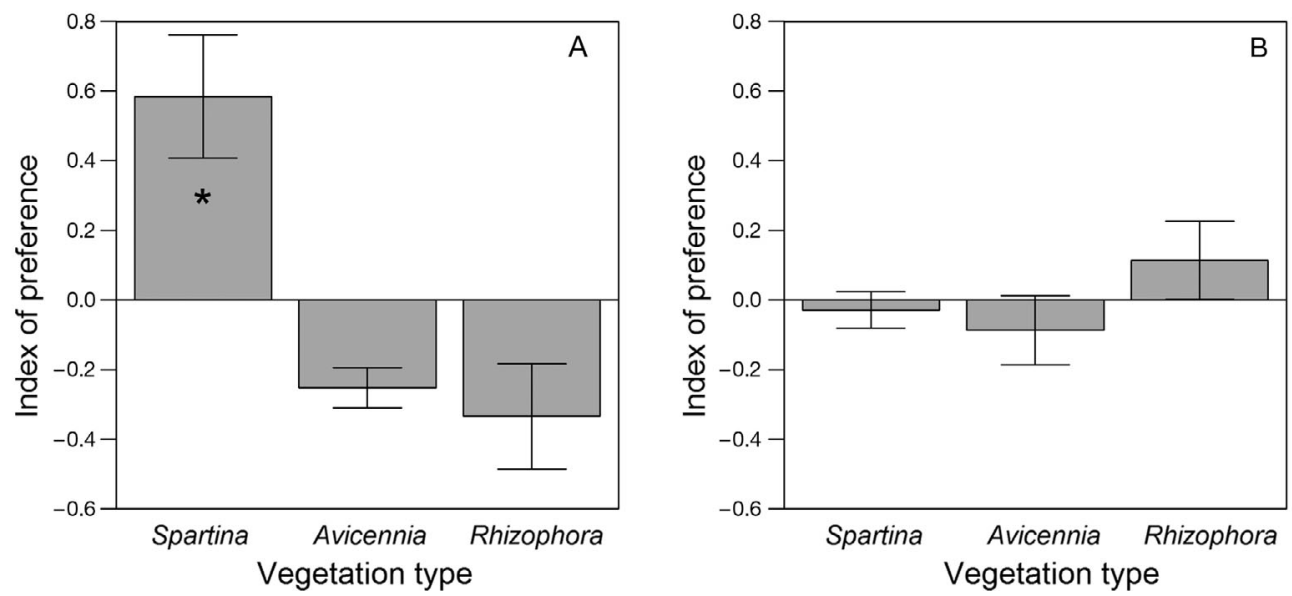

Fig. 5. Callinectes preference for vegetation types in the presence of predator cues during (A) fall (August and September) and (B) spring (May) laboratory studies. Values $>0$ indicate preference; values $<0$ indicate avoidance. Asterisks indicate significant differences at $p<0.05$

spring (heterogeneity G-test by season: $\mathrm{df}=2, \mathrm{p}=$ 0.005, Fig. 5). In the fall and in the presence of risk, Spartina shoots were preferred over mangrove vegetation (individual G-test for fall: $\mathrm{n}=11$ trials, $\mathrm{df}=2$, $p=0.009$, Fig. 5A). No preference was evident in the spring (individual G-test for spring: $\mathrm{n}=21$ trials, $\mathrm{df}=$ $2, p=0.24$, Fig. 5B).

\section{Survival}

Stronger preference in the presence of predator cues suggests that preferred habitats confer higher survival, so we also evaluated settler survival in each vegetation type. Among the 3 vegetation types tested, only Spartina shoots provided a probability of survival $(0.54 \pm 0.07 \mathrm{SE})$ that was significantly higher than the unvegetated treatment $\left(0.23 \pm 0.06 \mathrm{SE}_{\text {; }}\right.$ residual $\mathrm{df}=56, \mathrm{p}=0.028$; Fig. 6 ).

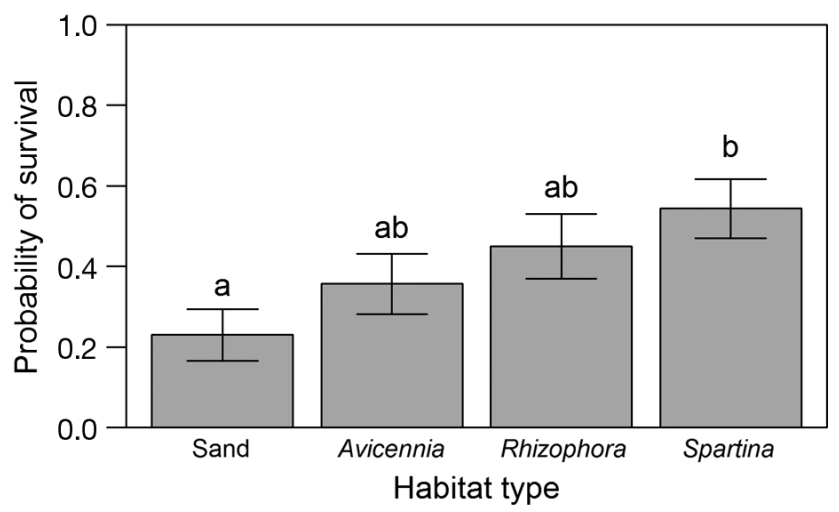

Fig. 6. Callinectes settler survival by vegetation type in the presence of a portunid predator. Lettering indicates significant differences at $\mathrm{p}<0.05$

\section{DISCUSSION}

Climate change is redistributing foundation species, with the potential to affect the population dynamics of inhabitant species if alternative habitats differ in quality. We used studies of recruitment, preference, and survival to determine the suitability of mangrove and marsh vegetation as habitat for post-settlement stage Callinectes. We expected habitat use to be vegetation-dependent, with use reflecting differences in preference for and survival in a given vegetation type. Habitat use in the field revealed that recruits favor Rhizophora habitat and Spartina shoot structures. Independent experimentation in the laboratory demonstrated that recruits preferred Spartina in the presence of predation risk, and that it was the only vegetation that significantly increased recruit survival compared to unvegetated conditions. Our results confirm that habitat use is vegetation-dependent and reveal that Spartina provides superior habitat; the driver of high recruitment into apparently unfavorable Rhizophora habitat remains to be identified, but vegetation structural attributes are likely influential (see the Supplement at www.int-res.com/articles/suppl/m573p001_supp.pdf).

\section{Recruitment}

Patchy recruitment has the potential to reduce settlement-based population attrition if recruits preferentially settle in habitats that provide higher probability of survival (Dahlgren \& Eggleston 2000, Halpin 2000, Johnston \& Lipcius 2012). The evolution of transient, mobile settler stages (e.g. megalopae) is 
attributed in part to the importance of finding and recruiting to optimal habitat by recognizing and choosing among cues for structure, food, and reduced predation (Welch et al. 1997, Rittschof et al. 1998, Tapia-Lewin \& Pardo 2014). Settling recruits responded to both patch-level habitat cues and isolated vegetation structures. Recruitment was 4 -fold higher in patches of Rhizophora and 2-fold higher in Spartina compared to neighboring Avicennia. Although recruitment was higher at the mangrovedominated site, recruitment was high to Rhizophora habitat regardless of its prevalence in the surrounding landscape (i.e. mangrove- or marsh-dominated sites). Recruitment was also 3-fold higher in grass shoots than in either other vegetation structure. Recruitment peaked simultaneously across the landscape, indicating that initial differences in abundance arose immediately upon recruitment, rather than due to secondary dispersal (Heck et al. 2001, Moksnes 2002, Moksnes \& Heck 2006). These patterns of Callinectes habitat use suggest that recruits respond most positively to non-structural attributes provided by Rhizophora and to structure formed by Spartina.

Callinectes often distinguish between habitats upon initial settlement (Welch et al. 1997, Moksnes \& Heck 2006, Johnston \& Lipcius 2012); however, settlement patterns are not always indicative of later population distribution, which is more readily attributed to juvenile survival and secondary dispersal (Heck et al. 2001, Moksnes 2002, Moksnes \& Heck 2006). Thus, recruit persistence was expected to vary by habitat according to quality. Often, recruit arrival alone may indicate sufficient differences in habitat quality to impact population dynamics, especially for species that are vulnerable to predation (Levin \& Stunz 2005, Almany \& Webster 2006, Baker et al. 2014). For Callinectes, the benefit of selecting one habitat over another may be relatively short lived, such that recruit persistence likely provides additional insight into habitat quality through duration of habitat use and as a proxy for post-settlement mortality (Houde 1987, Etherington \& Eggleston 2000, Heck et al. 2001). Between peak recruitment in late September and the next sampling event in early October, recruit persistence in Rhizophora was only half that documented in the neighboring habitat types. Thus, within 2 wk, lower persistence in Rhizophora habitat eliminated differences in settler abundance between $R h i$ zophora and Spartina habitat. A comparable trend emerged across vegetation structures, reducing structure-based differences in habitat use within 2 wk, though mean Callinectes abundance remained nearly double in favored prop root and shoot structures compared to pneumatophores. Continued recruit loss over time could be explained by a number of mechanisms. (1) Mortality would lead to decreasing recruit abundance over time. (2) Redistribution could also lead to decreased occurrence, but secondary dispersal is unlikely to be confounding because the sampled crabs did not exceed $20 \mathrm{~mm} \mathrm{CW}$, the expected size at secondary dispersal (Lipcius et al. 2007, Pardo et al. 2007, Johnston \& Lipcius 2012). (3) It is possible that recruit attrition was due in part to less effective capture of large or fast-swimming individuals with the panel retrieval method; however, finfish and swimming crabs ranging in size from 0.5 to $100 \mathrm{~mm}$ were regularly captured. Thus, some combination of mortality and local redistribution are the most likely explanations for recruit attrition. Ultimately, optimal habitat should host high initial arrival, followed by recruit persistence; these conditions were most apparent in Spartina habitat. The differences in habitat use between vegetation types may originate from some combination of active preference and post-settlement mortality, so we evaluated each in turn.

\section{Preference}

Juvenile habitat use is driven foremost by mortality avoidance (Dahlgren \& Eggleston 2000, Halpin 2000, Johnston \& Lipcius 2012), so preference for a specific habitat should reflect its structural complexity and value as a refuge, especially in the presence of predation risk (Schofield 2003, van Montfrans et al. 2003, Brooker et al. 2013). Recruit habitat preference was consistently stronger in the presence of predator cues, suggesting that habitat is selected for refuge. The only clear habitat preference emerged for Spartina in the fall, though low statistical power in preference trials means that failure to reject the null of no difference between vegetation types should be interpreted cautiously. The origin of seasonal variation is unknown, but it may relate to grass emergence in spring and senescence in fall. This hypothesis is supported in part by crab preference for Spartina wrack and detritus as structural refuge (Smith et al. 2016).

Although juvenile portunid crabs are voracious and effective predators on conspecific megalopae, in the preference study, juvenile cues could have been perceived as either conspecific or predator cues (Hines \& Ruiz 1995, Smith 1995, Moksnes et al. 1997, Aumann et al. 2006). Conspecific cues enhance 
settlement and metamorphosis (Forward et al. 2001, Diele \& Simith 2007), while predator cues generally reduce metamorphosis or accentuate habitat choices (Moksnes et al. 1997, Welch et al. 1997). If the juvenile cue treatment was perceived as conspecifics, we would have expected settler distributions to remain even among habitat types. If anything, conspecific cues should increase the rate of metamorphosis, resulting in more first instar juveniles (J1s) recovered from megalopae trials with the cue treatment. Instead, differences in habitat use became stronger and recovery of metamorphosed J1s was reduced by more than half in the presence of juvenile cues $(1.2$ compared to 3.6 average J1 recovered per habitat). Both results indicate that juveniles were perceived as predators rather than conspecific settlement cues. Thus, consistently stronger preferences in the presence of predation risk suggests that preferred habitats are likely of higher quality and should confer higher probability of survival.

\section{Survival}

In studies that compare vegetated (i.e. seagrass and salt marsh) habitat to mud and sand areas, the vegetated habitats often enhance survival of juvenile fish and invertebrates (Heck et al. 2001, Minello et al. 2003, but see Horinouchi et al. 2009). Vegetation also enhanced survival of settlers in this study. The variation in survival probability among vegetation types suggests that (1) survival depends on the refuges provided by vegetation structures and that (2) not all vegetation structure provides equally beneficial habitat. In particular, survival was highest in Spartina vegetation. Differences in survival likely originate from differences in refuge quality, particularly sizescaling and influences of vegetation structure on relative predator and prey mobility (Bartholomew et al. 2000). Spartina's thin but high-density branched architecture (i.e. long leaves diverging from stems) may provide the most effective size-scaling between vegetation structures and small settling crabs. Similarly, Callinectes sapidus survive better in finely branching macroalgae than in structurally simpler seagrass in Chesapeake Bay (Johnston \& Lipcius 2012).

Notably, the influences of habitat on survival may change with vegetation density if survival thresholds exist for structural features (Gotceitas \& Colgan 1989, Hovel \& Lipcius 2001, Scheinin et al. 2012). In this study, we used relatively low vegetation densities compared to mean natural densities of Spartina, Rhizophora, and Avicennia; further studies are needed to assess the relationship between survival in mangrove and marsh vegetation across a broader range of densities to determine if and where survival thresholds may exist, and how they differ among vegetation types. Nonetheless, our results provide initial evidence that marsh vegetation more strongly enhances recruit survival compared to mangrove vegetation, indicating that differences in ecotone vegetation use corresponds to differences in refuge quality, based in part on their structural forms.

\section{Implications of mangrove expansion}

This study demonstrates that the replacement of saltmarsh by mangroves is changing wetland habitat for Callinectes. Recruiting Callinectes selectively settled among mangrove and marsh vegetation types based on both structural and non-structural habitat attributes. The preferred Spartina shoots provided the highest probabilities of survival in laboratory experiments, suggesting that settlers can distinguish among ecotone vegetation types and that their choices correspond to habitat quality. Stronger preference in the presence of predation risk further supports the inference that selective settlement into Spartina is driven at least in part by mortality avoidance.

Based on these findings, Avicennia intrusion into saltmarsh represents effective habitat loss for Callinectes that may be partially alleviated with the subsequent emergence of Rhizophora. In both mangrove types, however, there is either low recruitment or low post-recruitment persistence. Recruits preferentially colonized Rhizophora habitat, but no evidence for preference or enhanced survival in the laboratory and poor recruit persistence in the field suggest that Rhizophora could represent an ecological trap or population sink (Battin 2004, Patten \& Kelly 2010). Thus, high recruit arrival there should not necessarily be interpreted as an indicator of good habitat quality. Given (1) the potential for survival to vary with habitat density (and our test of only low densities in the laboratory) and (2) the potential influence of arrival alone on population dynamics, additional tests of survival thresholds across vegetation densities and examination of habitat occupancy by older stages would help to clarify Rhizophora habitat quality for Callinectes.

Prior studies have reported contradictory evidence about the importance of structural and non-structural cues in Callinectes selection of habitat (Forward et al. 1996, Welch et al. 1997, Diaz et al. 1999). Here, Calli- 
nectes responded to both structural and non-structural cues when sorting among patchy, co-occurring wetland habitats. Our preliminary analyses suggest the potential importance of vegetation structural attributes, particularly the presence of branching, in mediating patterns of habitat use (see the Supplement). Additional studies will be needed to more explicitly determine (1) the non-structural attributes that shape habitat use and (2) differences in food availability and recruit growth rates among habitats. These studies would help identify the habitat attributes that stimulate high Callinectes settlement in suboptimal Rhizophora habitat, as differences in use could not be ascribed to the influence of structure alone. Many fish and invertebrates recruit to habitat with well-developed epifaunal communities, which suggests that non-structural cues, such as chemical odors associated with food, may attract Callinectes to Rhizophora prop roots (Laegdsgaard \& Johnson 2001, Verweij et al. 2006). Epifaunal prey communities may be more developed on prop roots than grass shoots that senesce annually, thus potentially contributing to higher Callinectes recruitment to Rhizophora in the field (Bishop et al. 2013).

With this study, mangroves and saltmarshes join the suite of habitats that Callinectes distinguish among during settlement. Even though Spartina wetlands often provide poorer habitat quality than co-occurring seagrass for nursery-stage marine fauna (Minello et al. 2003, Bloomfield \& Gillanders 2005), here we found that Spartina is superior habitat to tropical mangrove vegetation. As such, mangrove expansion is likely to have a negative impact on Callinectes populations. Callinectes are highly connected species within estuarine food webs (McCann et al. 2017); thus, diminished habitat quality for Callinectes with climate-driven wetland shifts is likely representative of changing conditions and cascading impacts for the broader estuarine macrofauna community (Scheffel et al. 2017). Beyond this system, these findings shed light on the habitat attributes that shape Callinectes habitat use. Their response to physical structure in the field, and corresponding results in the laboratory (see the Supplement ), indicates that shifts between habitats with differing structural attributes should be safely considered a change in habitat quality, especially in terms of survival. Thus, the displacement of one foundation species by another can alter habitat quality and availability without a net loss of structured habitat. Such shifts should be evaluated so that differences in quality can be taken into consideration when characterizing habitat availability and developing fisheries management plans.
Acknowledgements. This research was supported by NASA NNX11AO94G, NSF EF-1065098, the Society of Wetland Scientists, Sigma Xi, and a Link Foundation Marine Science Fellowship awarded to C.A.J. Analyses were conducted in part through ELME, a summer program at Michigan State University's Kellogg Biological Station supported by the NSF's Division of Environmental Biology through a supplement to OCE-0928819 to Christopher Klausmeier. Field assistance and logistical support were provided by J. Schefski, E. Steiber, D. Langley, E. Dark, M. Nathan, A. Forde, M. Edwards, L. Simpson, L. Duckett, M. Lehmann, W. Lee, S. Reed, H. Reichart, and volunteers of the Guana Tolomato Matanzas National Estuarine Research Reserve. Comments from D. S. Gruner and 3 anonymous reviewers greatly improved the manuscript. This article is contribution \#1064 for the Smithsonian Marine Station in Fort Pierce, Florida.

\section{LITERATURE CITED}

Almany GR, Webster MS (2006) The predation gauntlet: early post-settlement mortality in reef fishes. Coral Reefs 25:19-22

Aumann CA, Eby LA, Fagan WF (2006) How transient patches affect population dynamics: the case of hypoxia and blue crabs. Ecol Monogr 76:415-438

Baker R, Fujiwara M, Minello TJ (2014) Juvenile growth and mortality effects on white shrimp Litopenaeus setiferus population dynamics in the northern Gulf of Mexico. Fish Res 155:74-82

* Bartholomew A, Diaz RJ, Cicchetti G (2000) New dimensionless indices of structural habitat complexity: predicted and actual effects on a predator's foraging success. Mar Ecol Prog Ser 206:45-58

* Bates D, Maechler M, Bolker B, Walker S (2015) Fitting linear mixed-effects models using lme4. J Stat Softw 67: $1-48$

Battin J (2004) When good animals love bad habitats: ecological traps and the conservation of animal populations. Conserv Biol 18:1482-1491

* Bishop MJ, Fraser J, Gribben PE (2013) Morphological traits and density of foundation species modulate a facilitation cascade in Australian mangroves. Ecology 94:1927-1936

B Bloomfield AL, Gillanders BM (2005) Fish and invertebrate assemblages in seagrass, mangrove, saltmarsh, and nonvegetated habitats. Estuaries 28:63-77

Brainard R, Moffitt R, Timmers M, Paulay G (2009) Autonomous reef monitoring structures (ARMS): a tool for monitoring indices of biodiversity in the Pacific Islands. In: Proceedings of the 11th Pacific Science Inter-Congress, March 4, 2009. Papeete, Tahiti, p 197

Bretz F, Hothorn T, Westfall P (2016) Multiple comparisons using R. Chapman \& Hall/CRC Press, Boca Raton, FL

* Brooker RM, Munday PL, Mcleod IM, Jones GP (2013) Habitat preferences of a corallivorous reef fish: predation risk versus food quality. Coral Reefs 32:613-622

Cavanaugh KC, Kellner JR, Forde AJ, Gruner DS, Parker JD, Rodriguez W, Feller IC (2014) Poleward expansion of mangroves is a threshold response to decreased frequency of extreme cold events. Proc Natl Acad Sci USA 111:723-727

Dahlgren CP, Eggleston DB (2000) Ecological processes underlying ontogenetic habitat shifts in a coral reef fish. Ecology 81:2227-2240

Diaz H, Orihuela B, Forward RB Jr, Rittschof D (1999) Orien- 
tation of blue crab, Callinectes sapidus (Rathbun), megalopae: responses to visual and chemical cues. J Exp Mar Biol Ecol 233:25-40

* Diele K, Simith DJB (2007) Effects of substrata and conspecific odour on the metamorphosis of mangrove crab megalopae, Ucides cordatus (Ocypodidae). J Exp Mar Biol Ecol 348:174-182

Epifanio CE (1995) Transport of blue crab (Callinectes sapidus) larvae in the waters off mid-Atlantic states. Bull Mar Sci 57:713-725

Etherington LL, Eggleston DB (2000) Large-scale blue crab recruitment: linking postlarval transport, post-settlement planktonic dispersal, and multiple nursery habitats. Mar Ecol Prog Ser 204:179-198

* Feary DA, Almany GR, McCormick MI, Jones GP (2007) Habitat choice, recruitment and the response of coral reef fishes to coral degradation. Oecologia 153:727-737

Forward RB Jr, DeVries M, Rittschof D, Frankel DAZ, Bischoff JP, Fisher CM, Welch JM (1996) Effects of environmental cues on metamorphosis of the blue crab Callinectes sapidus. Mar Ecol Prog Ser 131:165-177

Forward RB, Tankersley RA, Rittschof D (2001) Cues for metamorphosis of brachyuran crabs: an overview. Am Zool 41:1108-1122

Friess DA, Krauss KW, Horstman EM, Balke T, Bouma TJ, Galli D, Webb EL (2012) Are all intertidal wetlands naturally created equal? Bottlenecks, thresholds and knowledge gaps to mangrove and saltmarsh ecosystems. Biol Rev Camb Philos Soc 87:346-366

Gotceitas V, Colgan P (1989) Predator foraging success and habitat complexity: quantitative test of the threshold hypothesis. Oecologia 80:158-166

* Griffiths CL, Richardson CA (2006) Chemically induced predator avoidance behaviour in the burrowing bivalve Macoma balthica. J Exp Mar Biol Ecol 331:91-98

Grol MGG, Nagelkerken I, Rypel AL, Layman CA (2011) Simple ecological trade-offs give rise to emergent crossecosystem distributions of a coral reef fish. Oecologia 165:79-88

*Halpin PM (2000) Habitat use by an intertidal salt-marsh fish: trade-offs between predation and growth. Mar Ecol Prog Ser 198:203-214

*Harley CDG, Randall Hughes A, Hultgren KM, Miner BG and others (2006) The impacts of climate change in coastal marine systems. Ecol Lett 9:228-241

Heck KL Jr, Coen LD, Morgan SG (2001) Pre- and postsettlement factors as determinants of juvenile blue crab Callinectes sapidus abundance: results from the northcentral Gulf of Mexico. Mar Ecol Prog Ser 222:163-176

Hines AH, Ruiz GM (1995) Temporal variation in juvenile blue crab mortality: nearshore shallows and cannibalism in Chesapeake Bay. Bull Mar Sci 57:884-901

Hoegh-Guldberg O, Bruno JF (2010) The impact of climate change on the world's marine ecosystems. Science 328 : 1523-1528

* Horinouchi M, Mizuno N, Jo Y, Fujita M, Sano M, Suzuki Y (2009) Seagrass habitat complexity does not always decrease foraging efficiencies of piscivorous fishes. Mar Ecol Prog Ser 377:43-49

Houde ED (1987) Fish early life dynamics and recruitment variability. Am Fish Soc Symp 2:17-29

Hovel KA, Lipcius RN (2001) Habitat fragmentation in a seagrass landscape: patch size and complexity control blue crab survival. Ecology 82:1814-1829

* Hsueh PW, McClintock JB, Hopkins TS (1993) Population dynamics and life history characteristics of the blue crabs Callinectes similis and C. sapidus in bay environments of the northern Gulf of Mexico. Mar Ecol 14:239-257

Johnston CA, Lipcius RN (2012) Exotic macroalga Gracilaria vermiculophylla provides superior nursery habitat for native blue crab in Chesapeake Bay. Mar Ecol Prog Ser 467:137-146

Knowlton N (2001) The future of coral reefs. Proc Natl Acad Sci USA 98:5419-5425

* Laegdsgaard P, Johnson C (2001) Why do juvenile fish utilise mangrove habitats? J Exp Mar Biol Ecol 257: 229-253

*Levin PS, Stunz GW (2005) Habitat triage for exploited fishes: Can we identify essential 'Essential Fish Habitat?'. Estuar Coast Shelf Sci 64:70-78

Lindsey EL, Altieri AH, Witman JD (2006) Influence of biogenic habitat on the recruitment and distribution of a subtidal xanthid crab. Mar Ecol Prog Ser 306:223-231

KLing SD (2008) Range expansion of a habitat-modifying species leads to loss of taxonomic diversity: a new and impoverished reef state. Oecologia 156:883-894

Lipcius RN, Eggleston DB, Heck KL, Seitz RD, van Montfrans J (2007) Ecology of postlarval and young juvenile blue crabs. In: Kennedy VS, Cronin LE (eds) The blue crab, Callinectes sapidus. University of Maryland Sea Grant Press, College Park, MD, p 535-564

* McCann MJ, Able KW, Christian RR, Fodrie FJ and others (2017) Key taxa in food web responses to stressors: the Deepwater Horizon oil spill. Front Ecol Environ 15: 142-149

McGaw IJ, Reiber CL (2000) Integrated physiological responses to feeding in the blue crab Callinectes sapidus. J Exp Biol 203:359-368

* Minello TJ, Able KW, Weinstein MP, Hays CG (2003) Salt marshes as nurseries for nekton: testing hypotheses on density, growth and survival through meta-analysis. Mar Ecol Prog Ser 246:39-59

Moksnes P (2002) The relative importance of habitat-specific settlement, predation and juvenile dispersal for distribution and abundance of young juvenile shore crabs Carcinus maenas L. J Exp Mar Biol Ecol 271:41-73

Moksnes PO, Heck KL Jr (2006) Relative importance of habitat selection and predation for the distribution of blue crab megalopae and young juveniles. Mar Ecol Prog Ser 308:165-181

Moksnes PO, Lipcius RN, Pihl L, van Montfrans J (1997) Cannibal-prey dynamics in young juveniles and postlarvae of the blue crab. J Exp Mar Biol Ecol 215:157-187

* Orth RJ, van Montfrans J (1987) Utilization of seagrass meadow and tidal marsh creek by clue crabs Callinectes sapidus. I. Seasonal and annual variations in abundance with emphasis on post-settlement juveniles. Mar Ecol Prog Ser 41:283-294

* Osland MJ, Enwright N, Day RH, Doyle TW (2013) Winter climate change and coastal wetland foundation species: salt marshes vs. mangrove forests in the southeastern United States. Glob Change Biol 19:1482-1494

* Pardo LM, Palma AT, Prieto C, Sepulveda P, Valdivia I, Ojeda FP (2007) Processes regulating early post-settlement habitat use in a subtidal assemblage of brachyuran decapods. J Exp Mar Biol Ecol 344:10-22

Patten MA, Kelly JF (2010) Habitat selection and the perceptual trap. Ecol Appl 20:2148-2156

* Paula J, Dray T, Queiroga H (2001) Interaction of offshore and inshore processes controlling settlement of brachy- 
uran megalopae in Saco mangrove creek, Inhaca Island (South Mozambique). Mar Ecol Prog Ser 215:251-260

Poloczanska ES, Brown CJ, Sydeman WJ, Kiessling W and others (2013) Global imprint of climate change on marine life. Nat Clim Chang 3:919-925

R Core Team (2015) R: a language and environment for statistical computing. R Foundation for Statistical Computing, Vienna. www.r-project.org

Rittschof D, Forward RB, Cannon G, Welch JM and others (1998) Cues and context: larval responses to physical and chemical cues. Biofouling 12:31-44

Robertson AI, Duke NC (1987) Mangroves as nursery sites: comparisons of the abundance and species composition of fish and crustaceans in mangroves and other nearshore habitats in tropical Australia. Mar Biol 96:193-205

Rodriguez W, Feller IC, Cavanaugh KC (2016) Spatiotemporal changes of a mangrove-saltmarsh ecotone in the northeastern coast of Florida, USA. Glob Ecol Conserv 7:245-261

Saintilan N, Wilson NC, Rogers K, Rajkaran A, Krauss KW (2014) Mangrove expansion and salt marsh decline at mangrove poleward limits. Glob Change Biol 20: $147-157$

Scheffel WA, Heck KL, Rozas LP (2017) Effect of habitat complexity on predator-prey relationships: implications for black mangrove range expansion into Northern Gulf of Mexico salt marshes. J Shellfish Res 36:181-188

Scheinin M, Scyphers SB, Kauppi L, Heck KL, Mattila J (2012) The relationship between vegetation density and its protective value depends on the densities and traits of prey and predators. Oikos 121:1093-1102

Schofield PJ (2003) Habitat selection of two gobies (Microgobius gulosus, Gobiosoma robustum): influence of structural complexity, competitive interactions, and presence of a predator. J Exp Mar Biol Ecol 288:125-137

Sepúlveda-Lozada A, Mendoza-Carranza M, Wolff M, SaintPaul U, Ponce-Mendoza A (2015) Differences in food web structure of mangroves and freshwater marshes: evidence from stable isotope studies in the Southern Gulf of Mexico. Wetlands Ecol Manage 23:293-314

Sharpe D (2015) Your chi-square test is statistically significant: now what? Pract Assess, Res Eval 20:1-10

Editorial responsibility: Ivan Nagelkerken, Adelaide, South Australia, Australia
Smee DL, Weissburg MJ (2006) Hard clams (Mercenaria mercenaria) evaluate predation risk using chemical signals from predators and injured conspecifics. J Chem Ecol 32:605-619

Smith LD (1995) Effects of limb autotomy and tethering on juvenile blue crab survival from cannibalism. Mar Ecol Prog Ser 116:65-74

Smith RS, Osbourne TZ, Byers JE (2016) Engineering community change from the bottom-up: mangrove expansion alters detrital invertebrate community composition. Mangrove \& Macrobenthos Meeting, July 2016, St. Augustine, FL

Stachowicz JJ, Terwin JR, Whitlatch RB, Osman RW (2002) Linking climate change and biological invasions: ocean warming facilitates nonindigenous species invasions. Proc Natl Acad Sci USA 99:15497-15500

* Steneck RS, Graham MH, Bourque BJ, Corbett D, Erlandson JM, Estes JA, Tegner MJ (2002) Kelp forest ecosystems: biodiversity, stability, resilience and future. Environ Conserv 29:436-459

Tankersley RA, Welch JM, Forward RB (2002) Settlement times of blue crab (Callinectes sapidus) megalopae during flood-tide transport. Mar Biol 141:863-875

Tapia-Lewin S, Pardo LM (2014) Field assessment of the predation risk-food availability trade-off in crab megalopae settlement. PLOS ONE 9:e95335

* van Montfrans J, Ryer CH, Orth RJ (2003) Substrate selection by blue crab Callinectes sapidus megalopae and first juvenile instars. Mar Ecol Prog Ser 260:209-217

Venables WN, Ripley BD (2002) Modern applied statistics with S, 4th edn. Springer, New York, NY

Verweij MC, Nagelkerken I, de Graaff D, Peeters M, Bakker EJ, van der Velde G (2006) Structure, food and shade attract juvenile coral reef fish to mangrove and seagrass habitats: a field experiment. Mar Ecol Prog Ser 306: 257-268

Welch JM, Rittschof D, Bullock TM, Forward RB Jr (1997) Effects of chemical cues on settlement behavior of blue crab Callinectes sapidus postlarvae. Mar Ecol Prog Ser 154:143-153

Wood S (2006) Generalized additive models: an introduction with R. Chapman \& Hall/CRC Press, Boca Raton, FL

Submitted: November 29, 2016; Accepted: April 29, 2017

Proofs received from author(s): June 1, 2017 